\title{
CONTROL OF BARBERRY BY 'SPOT-GUN' APPLICATION METHOD
}

\author{
F.A. MEEKLAH and R.B. MITCHELL
}

Invermay Agricultural Research Centre, MAF, Private Bag, Mosgiel

\section{SUMMARY}

Hexazinone 1.25 and $1.5 \mathrm{~g}$ ai and picloram/2,4,5-T $1+4$ and $1.5+6$ $\mathrm{g}$ ai/m of bush height were applied by 'Spot-gun' to either the soil or the basal stems of barberry (Berberis glaucocarpa), at 2 monthly intervals from February to December 1983 at two field sites near Kurow, North Otago. Hexazinone was the better herbicide for controlling barberry, with little difference between rates or times of application. Increasing the rate of picloram/2,4,5-T improved control with slightly better results from winter and early summer applications. Better control of barberry was achieved on steep stony soil than on relatively flat, less stony soil.

\section{INTRODUCTION}

The first paper presented to this conference on control of barberry (Berberis vulgaris, now B. glaucocarpa), reported field trials in the Whakatane district (Hewitt 1956). Comparisons were made between foliar sprays of several hormone herbicides, cut-stump applications of diesel/hormone mixtures, basal sprays of diesel/hormone mixtures to uncut trees, and soil surface applications of sodium chlorate and monuron. All treatments gave some degree of control, but a 2,4,5-T/diesel mixture was the most reliable, applied either to cut-stumps or as a complete basal spray. Barberry is now locally important in the Waikato, Bay of Plenty, Taranaki, Golden Bay, Canterbury and Otago. It decreases in importance further south (Bascand and Jowett 1982). In Waitaki County it is now the dominant shrub on the Kurow hill, and is spreading to surrounding districts, particularly where depleted tussock grassland coincides with low stocking pressure.

A barberry control study was carried out to confirm field reports (N. Daniel, R.W. Bristol, M.J. Cornwell pers comm) that spot-gun application of picloram $/ 2,4,5-\mathrm{T}$ or hexazinone gave satisfactory control, and to provide comparative data on time of application of these two herbicides. Results from the above study are reported in this paper.

\section{MATERIALS AND METHOD}

Two field experiments were laid down on the Kurow hill; Expt 1 on a steep sunny face (Omarama stony silt loam) and Expt 2 on a flat partially shaded area of the hill (Omarama silt loam).

Treatments were identical at both sites, and details of herbicides, rates and times of application are given in Table 1. Hexazinone (Velpar L) was applied by 'Spot-gun' undiluted to the soil surface on the uphill side of the bush, close to the crown. Picloram/2,4,5-T (Tordon Brushkiller DS), diluted with diesel and water in the ratio of $5: 2: 13$, was squirted on to the lower $30 \mathrm{~cm}$ of the stem or stems, from one side only. Bush height was measured at the time of application, and hexazinone applied at 1.25 or $1.9 \mathrm{~g} \mathrm{ai} / \mathrm{m}$ of height. Picloram $/ 2,4,5-\mathrm{T}$ was applied at $1+4$ or $1.5+6 \mathrm{~g}$ ai $/ \mathrm{m}$ bush height. Each treatment was replicated on five bushes selected at random.

Visual assessments of percentage dead wood/bush were made by three independent observers at intervals up to 21 April 1985. Climate observations were taken from meteorological station No. 140742 at Kurow.

Proc. 38th N.Z. Weed and Pest Control Conf. 
TABLE 1: Effect of herbicide rate and application time on 'Spot-gun' for control of barberry at two sites. Mean $\%$ dead wood/bush, assessed 21.4 .85 .

\begin{tabular}{lrrrrrr}
\hline \multirow{2}{*}{$\begin{array}{l}\text { Date of application } \\
\text { (Rate g ai/m bush ht) }\end{array}$} & \multicolumn{2}{c}{10.2 .83} & \multicolumn{2}{c}{11.4 .83} & \multicolumn{2}{c}{14.6 .83} \\
\hline & Exp 1 & 2 & Exp 1 & 2 & Exp 1 & 2 \\
hexazinone (1.25) & $99(4)$ & $100(5)$ & $100(5)$ & $83(4)$ & $100(5)$ & $96(3)$ \\
hexazinone $(1.9)$ & $100(5)$ & $88(4)$ & $100(5)$ & $58(2)$ & $100(5)$ & $96(3)$ \\
picloram/2,4,5-T (1+4) & $38(0)$ & $47(2)$ & $37(0)$ & $25(0)$ & $54(1)$ & $32(1)$ \\
picloram/2,4,5-T (1.5+6) & $62(1)$ & $57(2)$ & $61(1)$ & $57(2)$ & $95(1)$ & $34(1)$ \\
& & & & & & \\
& 4.8 .83 & 12.10 .83 & 14.12 .83 \\
hexazinone $(1.25)$ & $99(4)$ & $90(3)$ & $99(4)$ & $96(2)$ & $99(4)$ & $85(2)$ \\
hexazinone $(1.9)$ & $100(5)$ & $93(3)$ & $99(3)$ & $94(2)$ & $91(3)$ & $96(2)$ \\
picloram/2,4,5-T (1+4) & $80(3)$ & $41(3)$ & $85(3)$ & $55(1)$ & $88(3)$ & $53(1)$ \\
picloram/2,4,5-T (1.5+6) & $95(3)$ & $55(1)$ & $96(3)$ & $47(1)$ & $100(5)$ & $75(2)$ \\
\hline
\end{tabular}

( ) No. dead bushes out of five

\section{RESULTS}

The mean percentage dead wood/bush and the number of dead bushes in April 1985 is shown in Table 1 . Hexazinone was more successful in controlling barberry than was picloram $/ 2,4,5-\mathrm{T}$. There was no difference between the two rates of hexazinone or time of application.

Picloram $/ 2,4,5-\mathrm{T}$ gave poorer control at $1+4 \mathrm{~g} / \mathrm{m}$ than at $1.5+6 \mathrm{~g} / \mathrm{m}$ and control tended to be better from mid winter to December. This herbicide mixture also tended to reach its maximum effect quicker, i.e. in 10 to 16 months, compared with 18 to 20 months for hexazinone. Small bushes, below $1.5 \mathrm{~m}$ high, showed a higher percentage of dead wood with both chemicals.

Better control was achieved with both herbicides on the steep stony face than on the relatively flat partly shady area. On the latter site, analysis of time of application as a main effect showed that February application gave better results in terms of dead bushes (mean of both herbicides).

\section{DISCUSSION}

The experiments indicate the superiority of hexazinone over picloram/2,4,5-T when applied by 'Spot-gun' for barberry control. However because rates of kill were greater at the higher rate of picloram $/ 2,4,5-\mathrm{T}$, the threshold rate for maximum kill may not have been reached. With hexazinone, the absence of differences in percent dead wood between rates suggests that lower rate was either at, or even above, the threshold for maximum kill.

The small response to different times of application of hexazinone suggests that the absorption of small concentrated doses of herbicide applied by this method is not affected by time of application. However there was better control by picloram $/ 2,4,5-\mathrm{T}$ in August, October and December and this may be associated with the growth cycle of barberry which is in the latter stage of dormancy in August, reaching a peak in growth activity by December.

The reason for both herbicides giving poorer results on the flatter site is not obvious as the soil type was similar at both sites except for the steep site being stonier. Possibly bushes on the steeper stony site (Exp. 1) were under greater moisture stress and therefore more susceptible to herbicides.

The 'Spot-gun' method of application may be most suited to herbicides such as hexazinone, where a single 'spot' of chemical is probably sufficient to reach and enter plant roots, as indicated by Meeklah and Mitchell (1981) with sweet brier (Rosa rubiginosa). On the other hand, Bristol (1981) achieved good control of sweet brier with picloram $/ 2,4,5$-T applied by spot-gun when the herbicide was applied in a complete circle round the base of the bush. In our study, to simulate quick application with 
minimum labour input, application was from only one side. Despite the rates in our study being higher than those of Bristol (1981) this one-sided application did not give such good results.

Barberry up to $2.5 \mathrm{~m}$ in height growing on steep stony soils can best be controlled with hexazinone at $1.25 \mathrm{~g} \mathrm{ai} / \mathrm{m}$ bush height, applied by spot-gun. Barberry growing under less stressful conditions may be harder to control, and further investigations may be necessary to improve the degree of kill achieved.

\section{ACKNOWLEDGEMENTS}

The authors wish to thank the Noxious Plants Council for financial assistance with this project, and Mr P.D. Johnstone for biometrical advice and analyses.

\section{REFERENCES}

Bascand, L.D. and Jowett, G.H., 1982. Scrub weed cover of South Island agricultural and pastoral land. 2. N.Z. J. Exp. Agric: 455-492.

Bristol, R.W. 1981. Proc. 34th N.Z. Weed and Pest Control Conf.: 144-147.

Hewitt, S.R., 1956. Barberry control. Proc. 9th N.Z. Weed Control Conf.: 19-21.

Meeklah, F.A. and Mitchell, R.B., 1981. Evaluation of the spot-gun technique for control of sweet brier. 6th Aust. Weeds Soc. Conf.: 99-103. 